\title{
THE ROLE OF SHEARING IN THE PROTEROZOIC DEVELOPMENT OF THE ÅLAND ARCHIPELAGO, S.W. FINLAND
}

\author{
N. P. BRANIGAN
}

\begin{abstract}
BRANIGAN, N. P., 1987: The role of shearing in the Proterozoic development of the Åland archipelago, S.W. Finland. Bull. Geol. Soc. Finland 59, Part 2, $117-128$.

tion of a regional tectonochronology. Folds with E-W axial traces and associated shear zones which are characteristic of the southern Finland migmatite belt (1800 $\mathrm{Ma}$ ) were refolded during a late phase of NW-SE shearing. The resulting folds have a N-S or NW-SE axial trace and plunge parallel to lineations developed within the shear zones, i.e. $40-60$ to the south or south east. Shearing ceased for a period in which early-postorogenic ring complexes (c. $1815 \mathrm{Ma}$ ) were emplaced at high crustal levels. A subsequent succession of conjugate shears, with $\mathrm{N}-\mathrm{S}$ or NW-SE sinistral and NE-SW dextral displacement, tightened large fold profiles and affected the early-postorogenic intrusions, with the development of mylonites and ultramylonites. A change from a compressional to a tensile stress regime initiated normal faulting parallel to the NW-SE shears permitting the emplacement of the voluminous rapakivi massifs at or near the surface (c. $1500 \mathrm{Ma}$ ). The graben which developed were infilled by Jotnian (1300-1200 Ma) sediments. The major NWSE shear zone, which may extend across Sweden and into Estonia, overprints the southern Finland migmatite belt and has controlled the tectonic development and magmatic activity of the Aland area for some 600 million years.
\end{abstract}

Key words: structural analysis, deformation, folds, shear zones, Proterozoic, Snäckö, Seglinge, Kumlinge, Finland.

N. P. Branigan: Department of Geology, The University, Dundee DDI 4HN, Scotland.

\section{Introduction}

The Åland archipelago comprises some 10,000 islands and skerries in the Gulf of Bothnia to the south west of Turku (Åbo) in SW Finland (Fig. 1). The area consists of Svecofennian ortho and para gneisses, metamorphosed to upper amphibolite grade, interspersed between various syn-, late- and postorogenic granite bodies. The geology of the region was first described in detail by Sederholm in 1934 (Sederholm 1967), and specific aspects of the geology have been described by Kaitaro (1953), Ehlers (1976, 1978), Ehlers and
Ehlers (1977), Ehlers and Bergman (1984), Edelman and Jaanus-Järkkälä (1983), Bergman (1986), Hubbard and Branigan (1987) and Branigan (1987).

This paper developed out of the mapping of the Seglinge ring complex (Fig. 3), a member of the early-postorogenic igneous suite or Third group of granites of Sederholm (1967), and described by Hubbard and Branigan (1987) and Branigan (1987). This group of intrusions within the Åland archipelago was thought previously to be unaffected by major Svecofennian deformation (e.g. Berthelsen and Marker 1986). 
To the east of the Aland archipelago, the tectonic sequence is well known (Hopgood et al. 1976; Hopgood et al. 1983; Hopgood 1984) and characterised by a strong E-W structural trend. Within the Aland archipelago, however, the E$\mathrm{W}$ trend is sharply deflected into a NW-SE direction (Fig. 1) and the fabric becomes dominated by large open to tight folds with a similar axial direction (Ehlers 1978; Edelman and Jaanus-Järkkälä 1980, 1983). These folds are late in the tectonochronology and refold a sequence of earlier structures. The early structures will be briefly described but have not been studied in sufficient detail to permit more than a general deformation sequence to be constructed. The area studied (Snäckö and Seglinge, south of Kumlinge) has been described by Ehlers (1978).

\section{Early deformation (De)}

No systematic study of these early structures has been undertaken. They may, however, be divided into three groups on the basis of style. The earliest folds recognised are small scale (amplitude c. $5 \mathrm{~cm}$ ) intrafolial isoclinal folds, with gently dipping hinge lines which may, themselves, be isoclinally folded. These structures are most easily recognised within banded amphibolites, folding the metamorphic seggregation banding, where they occur as rootless closures as a result of internal flattening normal to the foliation. The intrafolial structures are refolded by tight to isoclinal folds with gently plunging fold axes parallel to the gneissosity. These folds have a regular to irregular similar-type profiles with highly attenuated limbs (Fig. 2a). The hinge zone is commonly crenulated. The folds may be symmetrical or asymmetrical and have an amplitude of c. $30 \mathrm{~cm}$. A third group of folds are distinctly asymmetrical $\mathrm{S}$ or $\mathrm{Z}$ folds with gently plunging axes and axial planes slightly oblique to the plane of foliation. These folds are invariably related to foliation-parallel shear and one limb is commonly sheared out (Fig. 2b).

\section{Large scale folding $(\mathrm{De}+1)$}

Large scale folding is the major structural feature of the Åland region, and refolds all earlier structures. This phase of deformation is related to the distinct deflection of the regional trend from E-W to NW-SE within the Aland archipelago and is absent in areas to the east (see Hopgood 1984).

Evidence for a late phase of deformation in the archipelago is afforded by examination of the Snäckö synform (Fig. 3). Within this structure a number of shear zones, confined to the biotite gneisses, are folded by the synform. The shears form broad zones up to $300 \mathrm{~m}$ wide and display an increase in the intensity of strain towards the centre. At the margins of these zones there is a sparse development of large $(5 \mathrm{~cm})$ euhedral $\mathrm{K}$ feldspar crystals aligned in the gneissosity. There is a gradual increase in the K-feldspar content of the gneiss producing a coarse granular granitic rock containing biotite schlieren towards the centre of the zones. In certain outcrops the granitic gneiss is »eyed» by clots of biotite and sometimes garnet aggregates mantled by quartz and microcline, developed by in-situ differentiation during shearing (Cheshall and Phillips 1980). In the centre of these zones there is a transition to an augen K-feldspar-biotite gneiss and ultimately mylonite (Fig. 2f). In the Kemiö area to the east, within the E-W trending belt, zones of intense shearing are reported which are intruded by post-metamorphic and syn- to postorogenic pegmatites and granites (Dietvorst 1982). It is here proposed that the shear zones which are folded within the Snäckö synform are of similar age to those in the Kemiö area.

The Snäckö synform (Fig. 3) is a large »open» cylindrical fold (Ehlers 1978), with a southerly plunging fold axis (Figs. 4a and b). The limbs of the fold are strongly flattened with the development of banded gneisses. Geniculate asymmetrical folds (Fig. 2c) folding these banded gneisses have axial planes oblique (c. $40^{\circ}$ ) to the plane of foliation, and fold axes with highly variable 


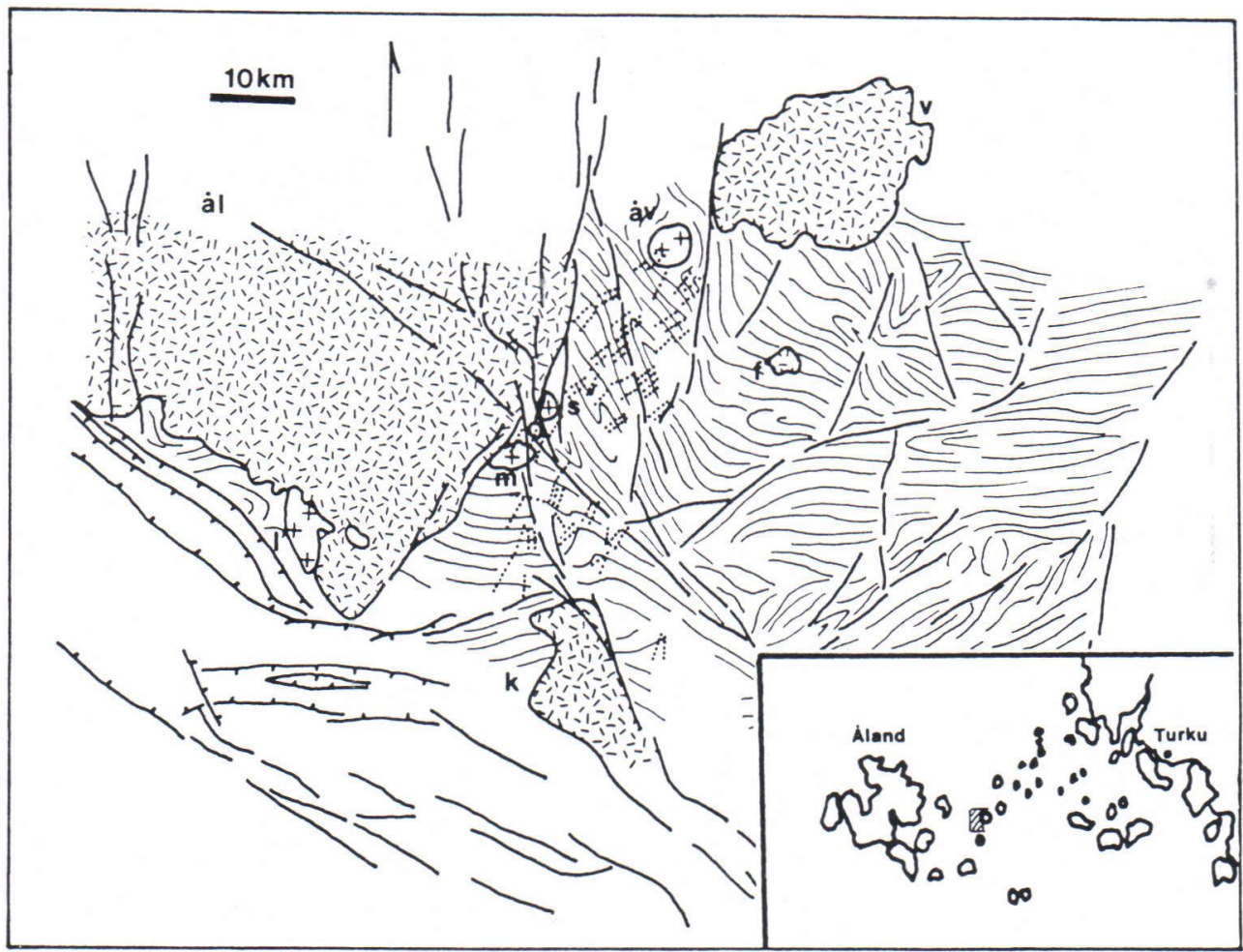

Fig. 1. A tectonic map of the Alland archipelago. The coastline and islands have been omited for clarity. The inset indicates the total region depicted on the map. The shaded area in the inset shows the position of the Seglinge-Snäckö area. Key: Stippled areas = The rapakivi granites, ål- Åland, v- Vehmaa, f- Fjälskär, k- Kökar; Crosses = early-postorogenic complexes, åv- Åva, s- Seglinge, m- Mosshaga, l- Lemland; Dotted lines indicate the diabase dyke swarm; Bold lines indicate major lineaments; Faint lines indicate the main foliation trends.

southerly plunge $\left(80^{\circ}-5^{\circ}\right.$, Fig. $\left.4 \mathrm{~b}\right)$. The calculated modal pole of the fold axis plunges to the south at $44^{\circ}$.

Along the western shore of Snäckö and on adjacent islands vertical sinistral shear zones with a N-S trend occur, in which coarse pegmatoid granites are reduced to coarse porphyroclastic protomylonite (Fig. 2g). Mineral lineations developed within these shear zones plunge between $85^{\circ}$ and $60^{\circ}$ to the south. The coincidence of the direction of plunge of the lineations and fold axes and the variable plunge of the minor fold axes suggests a close genetic link between shearing and folding. The wide range in minor fold axis plunges indicates that these axes were rotated into paral- lelism with the major structures due to high shear strains.

\section{Late superimposed folding $(\mathrm{De}+2)$}

Ehlers (1978) described a deformation event which bends the axial plane of the $\mathrm{Fe}+1$ structures. Within the area investigated evidence for this deformation is sparse. However, Bowden (1976) indicated that the $\mathrm{Fe}+1$ axial plane is refolded symmetrically within an open antiformal structure, indicating that the axial surfaces of the two fold phases were sub-perpendicular (Ramsay 1967). In the area under discussion the $\mathrm{Fe}+2$ 

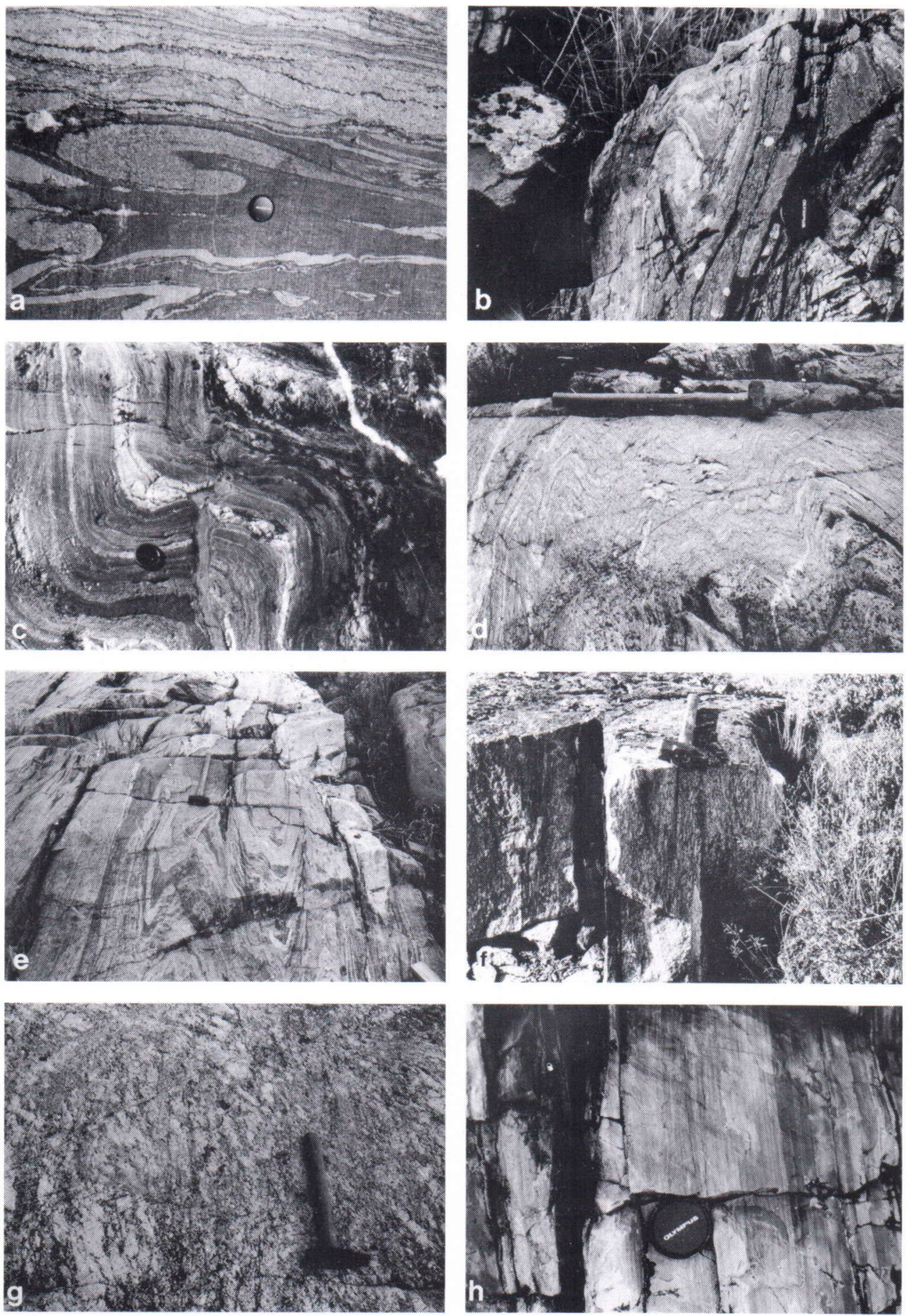

Fig. 2. Photographs illustrating typical small scale structural features present in the Aland archipelago. a. Fe fold, second type, Åva; b. Fe fold, third type, mid Snäckö; c. Fe +1 geniculate fold, W.Snäckö; d. Fe + 3 similar fold, Åva; e. Fe +4 similar folds, S.W.Snäckö; f. De protomylonite in biotite gneiss, mid Snäckö; g. De + 1 protomylonitic coarse alkali feldspar granite. Ådö; h. De +4 ultramylonite, N.W.Snäckö. 
axial plane trends NW-SE with fold axes plunging $15^{\circ}$ to the SE (Fig. $4 \mathrm{c}$ ).

\section{Gneissic downfolding (De +3$)$}

In the archipelago a distinct late deformation is restricted to the immediate vicinity of the earlypostorogenic igneous ring complexes of Åva and Seglinge (Fig. 1). Gneissic downfolding forms a rim syncline, due to the rise of a late-orogenic microcline granite diapir prior to the emplacement of the Ava and Seglinge ring complexes (Ehlers and Bergman 1984; Hubbard and Branigan 1986), in a manner similar to that described for the rapakivis of south Greenland (Bridgewater et al. 1974; Becker and Brown 1984). The effects of this deformation do not extent into the surrounding gneisses for a distance greater than the diameter of the granite (c. $6 \mathrm{~km})$. The downfolding is best displayed around the Ava complex, as compared with the Seglinge structure which is affected by post-ring complex shearing. Within the downfolded gneisses, early folds are conformable with the gneissosity with gently plunging fold axes. Local shearing parallel to the gneissosity is widespread and conformable with the ring structure. The radial system of lamprophyre dykes at Åva, which cuts the igneous ring complex (Kaitaro 1953, 1956), frequently displays sheared contacts and may have been emplaced along reactivated radial fractures related to the diapiric deformation phase.

Minor folding associated with the downfolding is developed only locally. At Ava, within the migmatite zone immediately surrounding the central microcline granite diapir (Ehlers and Bergman, 1984) the $\mathrm{Fe}+3$ folds range from open to isoclinal with amplitudes of several metres and axial planes parallel to the gneissic foliation. Fold axes plunge gently between $10^{\circ}$ and $40^{\circ}$. Outwith the migmatite zone, the $\mathrm{De}+3$ deformation produces upright chevron folds, with amplitudes of $50 \mathrm{~cm}$ and gently plunging fold axes (Fig. 2d). The difference in style and amplitude of the folds developed in or out of the migmatite zone is primarily a reflection of the greater ductility of the migmatites. In the envelope of the Seglinge complex the $\mathrm{De}+3$ is modified by later $\mathrm{De}+4$ shearing, which is generally characterised by a strong banding of the gneisses. Within these gneisses complex fold interference structures occur which are very similar to structures produced in model experiments of diapiric granite emplacement (Ramberg 1970). The De +3 deformation on Seglinge is most clearly demonstrated within the gneissose granite exposed in the south of the island. The gneissose granite foliation has a NW-SE trend to the south of Seglinge. As the ring structure is approached a discrete transposed spaced foliation is developed with an $\mathrm{E}-\mathrm{W}$ trend which increases in intensity closer to the ring structure until the general foliation is uniformly $\mathrm{E}-\mathrm{W}$.

\section{Late shearing $(\mathrm{De}+4)$}

The early postorogenic Seglinge ring complex (Fig. 3) is highly sheared and only the eastern half of the complex is now exposed. The western half has been displaced $3.5 \mathrm{~km}$ to the south by sinistral shears and can be located beneath the sea by its geomagnetic anomaly (GSF map sheet 1014). To the east, the Seglinge complex is affected by NW-SE and N-S sinistral shears, incorporating slices of the complex which are displaced northwards to a maximum of $10.5 \mathrm{~km}$ (Ehlers and Ehlers 1981). On the western shore of Ådö (Fig. 3) the coarse porphyritic Seglinge granite is mylonitised. Lamprophyre dykes are disrupted and highly folded, with axes plunging $30^{\circ}$ to the south. Discrete mylonite or ultramylonite zones are developed within the earlier De +1 shears. Fibrous lineations in the mylonites plunge to the south or southeast at between $30^{\circ}-60^{\circ}$. Both the exposed half of the Seglinge complex and the Snäckö synform are cut by conjugate shear sets related to the major De +4 shears (Fig. 3).

The Seglinge complex comprises a central 


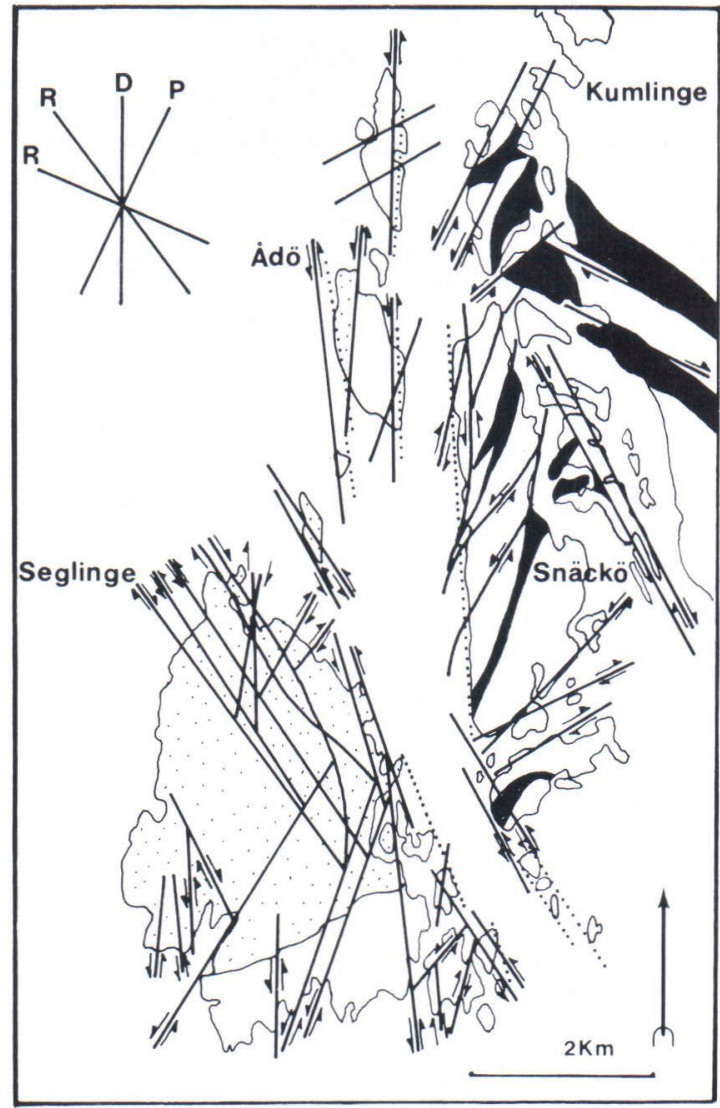

Fig. 3. A map of the Seglinge-Snäckö area (for location see inset in Fig. 1). Key: Black = De shear zones; dotted lines = $\mathrm{De}+1$ shear zones; bold lines $=\mathrm{De}+4$ shear zones; stippled areas $=$ Seglinge igneous complex. Orientation diagram and labels D, R, R' \& P indicate the distribution of De +4 shear sets in the area (for explanation, see text).

massive granodiorite - monzonite body surrounded by a system of steeply inwardly dipping ring intrusions (Hubbard and Branigan 1987; Branigan 1987). The shear system is confined to the marginal ring intrusions which indicates a strong posthumous control in the orientation and distribution of the shears. The characteristic mineralogy of the shears within rocks of the igneous complex is a quartz-epidote mylonite with recrystallised hornblende and biotite and microcline augen. Plagioclase is completely altered, and is recognised only as elongate streaks of sausserite within the foliation. Plagioclase is
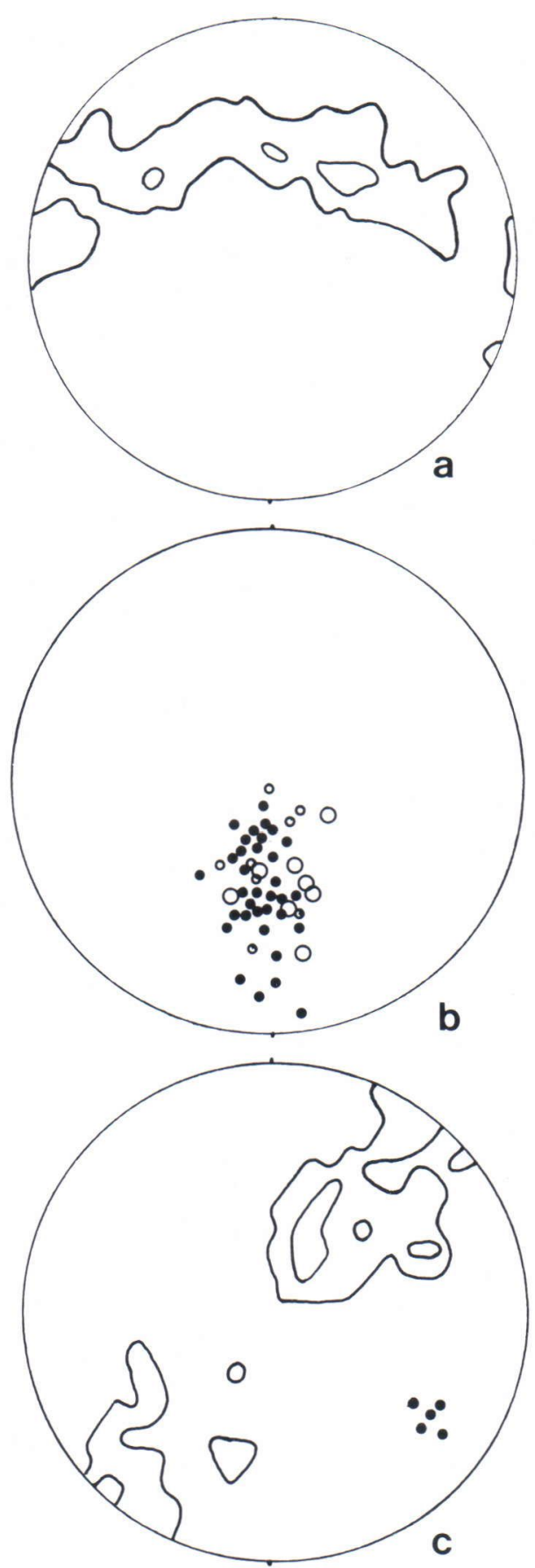

Fig. 4. Lower hemisphere stereographic projections of a. poles to foliation, $\mathrm{Fe}+1$ Snäckö synform, contored at 2 and $4 \%$ intervals, 460 data points; b. $\mathrm{Fe}+1$ minor fold axes (filled circles), De +1 shear zone lineations (large open circles) and $\mathrm{Fe}+4$ fold axes (small open circles); c. poles to foliation and fold axes (filled circles) in the $\mathrm{Fe}+2$ fold, S.W.Kumlinge, contoured at 2 and $4 \%$ intervals, 66 data points. 
not completely altered in the adjacent unsheared rock, although a red colouration is common, suggesting that the shears were zones of fluid transport.

The Snäckö synform is affected by a similar set of conjugate shears which have a sygmoidal form and to the west curve into parallelism with the major shear zone. Fabrics developed are mylonitic to ultramylonitic (Fig. 2h). Minor folding associated with these shears is the last folding event recognised $(\mathrm{Fe}+4)$. This produced similar folds with small amplitude $(<2 \mathrm{~m})$ frequently with small shear displacements parallel to the axial surface (Fig. 2h). Axial planes are parallel to the local shear zone foliation and the fold axes have variable plunge (Fig. 4b).

Late brittle shears, with a dextral sense, and vertical normal faults occur at high angles (NE$\mathrm{SW})$ to the major shears. In the granitic rocks this produced a coarse red-stained fault breccia. Within the amphibolitic rocks a fine chloritic gouge is developed. These faults may be infilled by diabase dykes, commonly with sheared margins, which are members of a regional NE-SW dyke swarm (Ehlers and Ehlers 1977).

\section{Analysis of shearing}

In wrench fault tectonics the principal stresses $(\sigma 1>\sigma 2>\sigma 3)$ are arranged with $\sigma 2$ in a vertical orientation. Where conjugate shear systems are developed the direction of $\sigma 1$ is obtained from the acute bisectrix of the convergent quadrant of the first order shears (Fig. 5). The MohrCoulomb criterion of fracture predicts that the angle $(\theta)$ between $\sigma 1$ and a shear plane is $45-\varnothing / 2$, where $\varnothing$ is the effective angle of internal friction. For most rocks the angle $\varnothing / 2$ is commonly $30^{\circ}-32^{\circ}$. Shear planes inclined at angles of $\varnothing / 2$ to the direction of movement (D) with a synthetic sense of displacement are Riedel shears (R). Conjugate Riedel shears ( $\mathrm{R}^{\prime}$ ) are orientated at $90-\varnothing / 2$ to the direction of movement (D). Further shears (P) may be formed at $-\varnothing / 2$ to the direction of movement (D) (Fig. 5), with the same

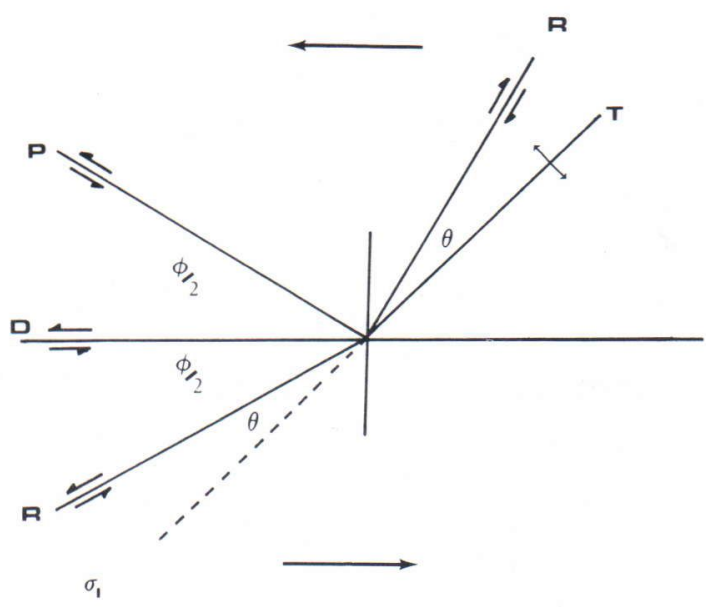

Fig. 5. Diagram to illustrate shear zone systematics, after Tchalenko \& Ambraseys (1970). The diagram depicts a sinistral displacement with an overall movement direction $\mathrm{D}$. A conjugate shear system R \& R' is formed at $\varnothing / 2$ and $90-\varnothing / 2$ respectively (where $ø / 2=30-32$ ). P-shears, with a similar sense of movement as the R-set, form at an angle of $-\varnothing / 2$ to D. Tensile fractures (T) may form at an angle $\theta(=45-\varnothing / 2)$ to $\mathrm{R}$ or R' (forming the acute bisectrix of the convergent quadrant) and are parallel to $\sigma 1$.

sense of displacement as the R-shears (Tchalenko and Ambraseys 1970).

A lineament map of the Aland archipelago has been constructed (Figs. 1 and 6) by contouring an isobath map derived from the marine chart of the region. The major shears control deep channels between the islands and may be easily recognised. The sense of displacement shown in Fig. 6 for the major shears is based on direct field observation, analysis of maps of the region (GSF map sheets 1023, 1014, 1021 \& 1012) and inferences based on these data.

Fig. 6 reveals several dominant fault directions. A major NW-SE system is located to the south and west of the area, while in the north the faults have a roughly $\mathrm{N}-\mathrm{S}$ orientation, and an $\mathrm{E}-\mathrm{W}$ orientation in the southeast. The $\mathrm{E}-\mathrm{W}$ system with dextral sense is parallel to the strong E-W foliation of the gneisses in this region. Sinistral shears, with a low angle intersection with the dextral set correspond to the Nötö area, in which Edelman and Jaanus-Järkkälä (1983) describe fan-shaped magnetic anomalies displaced to the 
north and north east. Any analysis of the shear system in this region is suspect on account of the strong posthumous control on shear orientations exerted by the pronounced structural grain of the region (Clifford 1962).

The shears of the Aland Archipelago can be integrated into a single shear system (see Fig. 5). The dominant $130^{\circ}$ trend suggests a set of sinistral Riedel shears $(\mathrm{R})$ whereas the sinistral $180^{\circ}$ set equates with the P-shears. The acute bisectrix $(\varnothing / 2=25)$ to these two sets provides the direction of movement $\mathrm{D}$ (155). The orientation of $\sigma 1$ inferred from these relationships (Stowe, 1980) is $118^{\circ}$ i.e. the maximum regional compression operated ESE-WNW. Dextral shears to the north of the region with a $030^{\circ}$ orientation correspond to the conjugate complimentary system of Riedel shears R'. The angle between the R and R' sets, however, exceeds that predicted by the Coulomb criterion. Two possibilities exist to explain this behaviour. First, the region is markedly inhomogeneous, both in terms of rock types and structure, and so Coulomb's criterion may not be applicable (Clifford 1962). Secondly, the shear box experiments of Tchalenko (1970) indicate that, due to the high angle to $\mathrm{D}$, the conjugate Riedels become passive and are subsequently rotated.

Within the Snäckö - Seglinge area (Fig. 3) the $\mathrm{De}+4$ shear pattern appears more complex. The major N-S sinistral shear between the islands of Snäckö and Seglinge is, in regional terms, a member of the P-set. Within this domain, however, $\mathrm{N}-\mathrm{S}$ is the direction of major displacement D. Associated Riedel shears (R) with a NW-SE direction form an angle with $\mathrm{D}$ of $30^{\circ}(=\varnothing / 2)$. The conjugate system of Seglinge may be resolved into a NW-SE sinistral set parallel to the R-set and a NE-SW sinistral set at an angle of $30^{\circ}$ $(=\varnothing / 2)$ to $\mathrm{D}$ forming the P-set. On Snäckö, the conjugate set may be resolved into a NE-SW sinistral set to the west parallel to the P-set and a NW-SE dextral set belonging to the R'-set. The R'-set make an angle of $60^{\circ}(=90-\varnothing / 2)$ to D. The orientation of $\sigma 1$ defined by this shear system within a small area is $110^{\circ}$ which is in close agreement with the orientation of $\sigma 1 \mathrm{de}$ rived above from the regional shear system of the archipelago.

Late brittle movements occurred within shears with a NE-SW orientation. These are associated with dextral movement and the emplacement of a regional set of diabase dykes (Fig. 1; Ehlers and Ehlers 1977). This is the first indication of a transition from a compressional to a tensile regime. Associated with this change is the emplacement of the rapakivi granites. Geophysical evidence (Laurén 1970) indicates that the rapakivi massifs have elongate keels orientated NW-SE. Crustal distention reactivated the NW-SE regional shear set as normal faults allowing the ascent of the rapakivi magmas. Jotnian sandstones were deposited in the resulting rift basins and were downfaulted by further movements.

\section{Timing of events}

Hopkood et al. (1983) state that the major deformation in the E-W trending belt of southern Finland occurred between $1895 \mathrm{Ma}$ and $1870 \mathrm{Ma}$, although migmatitic activity may have continued until $1800 \mathrm{Ma}$. Within the Åland archipelago, the emplacement of the early-postorogenic intrusions at $1815 \mathrm{Ma}$ (Vaasjoki 1977) marks a hiatus in the regional deformation between the $\mathrm{De}+1$ and $\mathrm{De}+2$ events and the $\mathrm{De}+4$ shearing. A hiatus in the deformation sequence is indicated by the absence of a regional post-De +2 folding episode, and the circular form of these complexes which is indicative of isotropic horizontal stress conditions (Koide and Bhattacharji 1975). Therefore, the De +1 folding and shearing, which is coincident with the marked swing in regional trend within the archipelago, and the $\mathrm{De}+2$ folding, occurred in the 55 million years between $1870 \mathrm{Ma}$ and $1815 \mathrm{Ma}$.

Ehlers and Ehlers (1977) consider the regional diabase dyke swarm (Fig. 1) to be of the same 
Fig. 6. A lineament map of the Alland archipelago indicating the major De +4 shear zones. The area depicted is the same as Fig. 1. Key: Postorogenic granites are stippled. Early postorogenic granites :- A = Ảva; $\mathrm{S}=$ Seglinge; $\mathrm{M}=$ Mosshaga $\mathrm{L}=$ Lemland. Rapakivi granites :- $\AA$ = Åland; V = Vehmaa; $\mathrm{K}=$ Kökar, $\mathrm{F}=$ Fjälskär. Orientation diagram and labels D, R, R' \& P refer to the distribution of the major $\mathrm{De}+4$ shear sets in the archipelago (for explanation, see text).

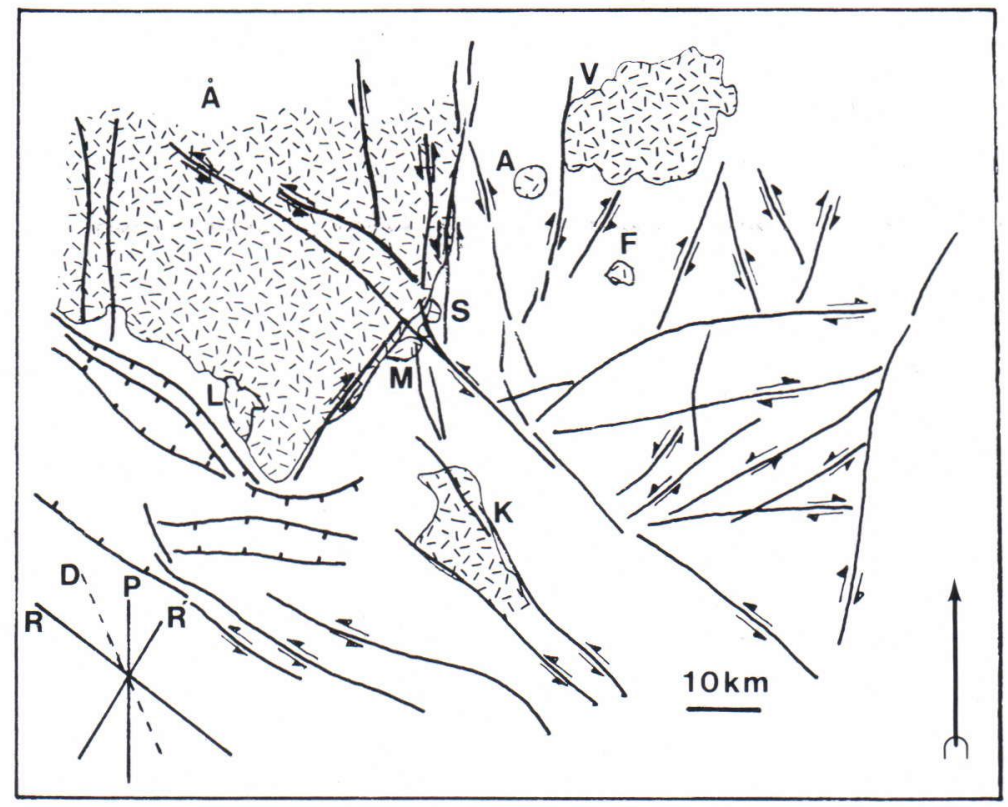

age as the Aland rapakivi granite massif. (c. 1670Ma; Vaasjoki 1977). As the emplacement of these dykes appears to be associated with late brittle movements of the Aland shear system, the extensive De +4 shearing must have occurred between $1815 \mathrm{Ma}$ and $1670 \mathrm{Ma}$. Normal faulting, by reactivation of the regional NW-SE shear system, continued during the period of Jotnian sandstone deposition (1300-1200Ma; Simonen 1980). Thus, the structural development of the Åland archipelago has been dominated by shearing and faulting, with a dominant NW-SE orientation, for at least $670 \mathrm{Ma}$ since $1870 \mathrm{Ma}$.

\section{Discussion}

It has been shown that between $1870 \mathrm{Ma}$ and $1670 \mathrm{Ma}$ a NW-SE shear belt in Åland was superimposed on the older (1890-1870Ma) EW trending migmatite belt of southern Finland. The Alland belt is parallel to the Ladoga-Skellefteå and Kemijärvi-Enontekiö lineaments in central and northern Finland respectively (Papu- nen and Vorma 1984). The Åland belt may extend south-eastwards into Estonia (Rotanfel'd et al. 1975) and north-westwards into Sweden along a line between Gävle and Trondheim (Berthelsen 1983). The long-lived Åland shear system is compatible with generation in response to an ENEWNW compression, and cannot be easily reconciled with the plate tectonic models for SW Finland of Hietanen (1975) and Edelman and JaanusJärkkälä (1983) which involve northerly subduction beneath SW Finland culminating in the docking of the Svecofennides with a southern plate comprising Estonia and southern Sweden. It should also be noted that the $\mathrm{De}+4$ ductile shearing event occurring in the Aland archipelago, which affects the early-postorogenic igeneous complexes of Åva, Seglinge and Mosshaga (Branigan 1987), postdates the major shear movements in the Baltic shield proposed in the recent tectonic model for the Baltic shield of Berthelsen and Marker (1986). Rather, southern Finland and Sweden have features in common with many ensiallic mobile belts of the same age worldwide (e.g. Anhausser et al. 1969), namely: 
(1) High grade (high T, low P) metamorphism (Eskola 1963; Dietvorst 1983; Edelman and Jaanus-Järkkälä 1983).

(2) Repeated strike-slip shearing (this paper).

(3) Repeated bimodal magmatic activity (Ehlers and Ehlers 1981) within a continental rift environment (Ehlers et al. 1986; Baker et al. 1982; Vivallo and Rickard 1984) and the emplacement of ring complexes (Ehlers and Bergman 1984; Hellingwerf and Baker 1985; Bergman 1986; Hubbard and Branigan 1987; Branigan 1987).

(4) Complex folding and refolding relationships (Ehlers 1978; Griffen 1979; Hopgood 1984; Ståhlhös 1984; this paper) with the coincidence of lineation and fold axes.

A preferred evolutionary model for SW Finland is one of ensiallic mobile belt development. In such a model, crustal attenuation resulted in the formation of fault controlled basins which became centres of sedimentation and volcanicity. Crustal underaccretion initiated the rise of calcalkaline granitoids and widespread crustal anatexis, leading to high geothermal gradients

\section{References}

Anhausser, C. R.; Mason, R.; Viljoen, M. J. \& Viljoen, R. $P ., 1969$. A reappraisal of some aspects of Precambrian shield geology. Geol. Soc. Am., Bull. 80, 2175-2200.

Anderson, E. M., 1957. The dynamics of faulting. Oliver \& Boyd, Edinburgh.

Baker, W.; de Maesschalk, S. \& van Meerten, T., 1982. Bimodal early Proterozoic volcanism in the Grythytte field and associated volcano-plutonic complexes, Bergslagen, Central Sweden. Geol. Rundsch. 71, 171-181.

Becker, S. M. \& Brown, P. E., 1985. Stoping versus ductile deformation in the emplacement of the rapakivi intrusion of Qernertoq, south Greenland. Bull. Geol. Soc. Denmark 33, 363-370.

Bergman, L., 1986. Structure and mechanism of intrusion of postorogenic granites in the archipelago of southwestern Finland. Acta Academie Aboensis, B 46 (5) 74 pp.

Berthelsen, A., 1984. The tectonic division of the Baltic shield. Proc. In Galsow, D. A. \& Mueller, St. (Eds.) First WEGT: northern segment. ESF, Strasbourg, pp. 13-22. and metamorphism (Wickham and Oxburgh 1985; Lux et al. 1986). Underplating and recompression resulted in crustal thickening and anatexis causing the late and postorogenic granite activity (e.g. Kröner 1979). Such a model requires a pre-Svecofennic (Archaean) continental crust which is traditionally held to be absent in southern Finland (Simonen 1980; Gaál 1985). However, the extensive mantle-crust interactions inherent in the model would have the effect of reworking the entire crust, leading to the possibility that the synorogenic granites of the archipelago may be remobilised basement material as has been suggested by Ehlers and Ehlers (1981). In this regard, it is interesting to note that Vaasjoki (1977) gives an Archaean U-Pb age of $2.75 \mathrm{Ga}$ for relict zircon cores from the Vehmaa rapakivi granite massif (Fig. 1).

Acknowledgements. The friendly cooperation and assistance of Professor C. Ehlers is gratefully acknowledged, as is the financial support of the University of Dundee. I would like to thank Dr F. H. Hubbard (Dundee), Professor D. M. Ramsay (Dundee) and Professor C. Ehlers (§̊bo) for critically reviewing an earlier draft of this manuscript.

— \& Marker, M., 1986. 1.9-1.8Ga old strike-slip megashears in the Baltic shield, and their plate tectonic implications. Tectonophysics $128,163-181$.

Bowden, P. L., 1976. The geology of the islands around N. Snäckö and Jugasholm (west of Kumlinge), Åland archipelago, southwest Finland. Unpubl. B.Sc. Thesis, Univ of Dundee.

Branigan, N. P., 1987. The geology, geochemistry and tectonic setting of the early-postorogenic ring complexes, Åland, S.W. Finland. Unpubl. Ph.D. Thesis, Univ. of Dundee.

Bridgewater, D.; Sutton, J. \& Watterson, J., 1974. Crustal downfolding associated with igneous activity. Tectonophysics $21,57-77$.

Chenkall, B. E. \& Phillips, E. R., 1980. Spotted structures in gneiss and veins from Broken Hill, New South Wales, Australia. Min. Mag. 43, 779-787.

Clifford, T. N., 1962. Influence of a posthumous control on the orientation of major fault systems. Geol. Soc. Am., Abstr. for 1961, Spec. Paper 68, 151-152.

Dietvorst, E. J. L., 1982. Prograde metamorphic zoning in 
amphibolite facies pelitic gneisses from Kemiö, southwest Finland. Geol. Rundsch. 71, 245-262.

Edelman, N. \& Jaanus-Järkälä, M., 1980. Stratigraphy and plate tectonics in the archipelago of southwestern Finland. Geol. Fören. Stockholm Förh. 102, 187.

— \& Jaanus-Järkkälä, M., 1983. A plate tectonic interpretation of the Precambrian of the archipelago of southwestern Finland. Geol. Surv. Finland, Bull. 325, 33 pp.

Ehlers, C., 1976. Homogeneous deformation in Precambrian supracrustal rocks in Kumlinge area, southwest Finland. Precambrian Res. 3, 481-504.

-, 1978. Gravity tectonics and folding around a basic centre in the Kumlinge area, S.W. Finland. Geol. Surv. Finland, Bull. 295, 33 pp.

- \& Bergman, L., 1984. Structure and mechanism of intrusion of two postorogenic granitic massifs, southwestern Finland. In Krömer, A. \& Greiling, R. (Eds.) Precambrian Tectonics Illustrated. Schweizerbart, Stuttgart, pp. 173-190.

- \& Ehlers, M., 1977. Shearing and multiple intrusion in the diabases of Aland archipelago, S.W. Finland. Geol. Surv. Finland, Bull. 289, 31 pp.

- \& Ehlers, M., 1981. Pre-Quaternary rocks of the Kumlinge map sheet area. Geol. Surv. Finland, Espoo, Finland.

Eskola, P., 1963. The Precambrian of Finland. In Rankama, K. (Ed.) The Precambrian, Vol. 1. Interscience, New York.

Gaál, G., 1985. Evolution of the Archean and Proterozoic crust in the northern and eastern Baltic shield. Symp. on the Baltic shield, Helsinki (abstr).

Griffen, V. S., 1979. Diapirism, polydeformation and amoeboidal tectonic patterns in the Svecofennedic area of southwestern Finland. Geol. Surv. Finland, Rep. Invest. $41,16 \mathrm{pp}$.

Hellingwerf, B. H. \& Baker, J. H., 1985. Wall rock alteration and tungsten and molybdenum mineralisation associated with older granites in western Bergslagen, Sweden. Econ. Geol. 80, 479-487.

Hietanen, A., 1975. Generation of potassium-poor magmas in the northern Sierra Nevada and the Svecofennian of Finland. J. Res. U.S. Geol. Surv. 3, 631-645.

Hopgood, A. M., 1984. Structural evolution of Svecokarelian migmatites, southern Finland: a study of Proterozoic crustal development. Trans. R. Soc. Edinburgh ESS 74, $229-264$.

-; Bowes, D. R. \& Addison, J., 1976. Structural development of migmatites near Skaldö, southwest Finland. Bull. Geol. Soc. Finland. 48, 43-62.

-; Bowes, D. R.; Kuovo, O. \& Halliday, A. N., 1983. $\mathrm{U}-\mathrm{Pb}$ and $\mathrm{Rb}-\mathrm{Sr}$ isotopic study of polyphase deformed migmatites in the Svecokarelides, southern Finland. In Atherton, M. P. \& Gribble, C. D. (Eds.) Migmatites, Melting and Metamorphism. Shiva Publishing, Cheshire.
Hubbard, F. H. \& Branigan, N. P., 1987. Late Svecofennian magmatism and tectonism, Åland, southwest Finland. Precambrian Res. 35, 241-256.

Kaitaro, S., 1953. Geological structure of the late-Precambrian intrusives in the Ava area, Aland islands. Bull. Comm. Geol. Finlande 162, 71 pp.

-, 1956. On central complexes with radial lamprophyre dykes. Bull. Comm. Geol. Finlande 172, 55-65.

Koide, H. \& Bhattacharji, S., 1975. Formation of fractures around magmatic intrusions and their role in ore localisation. Econ. Geol. 70, 781-799.

Kröner, A., 1979. Precambrian crustal evolution in the light of plate tectonics and the undulation theory. Geol. Mijnbow $68,231-240$.

Laurén, L., 1970. An interpretation of the negative gravity anomalies associated with the rapakivi granites and the Jotnian sandstones in southern Finland. Geol. Fören. Stockh. Förh. 92, 21-34.

Lux, D. R.; de Yoreo, J. J.; Guldotti, C. V. \& Decker, E. $R ., 1986$. Role of plutonism in low-pressure metamorphic belt formation. Nature 323, 794-796.

Papunen, H. \& Vorma, A., 1985. Nickel deposits in Finland, a review. In Papunen, H. \& Gorbunov, G. I. (Eds.) Nickel-Copper Deposits of the Baltic Shield and Scandinavian Caledonides. Geol. Surv. Finland, Bull. 333, 394 pp.

Ramberg, H. H., 1970. Model studies in relation to intrusion of plutonic bodies. In Newall, G. \& Rast, N. (Eds.) Mechanism of Igneous Intrusion. Geol. J. Spec. Issue 2, pp.

Ramsay, J. G., 1967. Folding and Fracturing of Rocks. McGraw-Hill New York.

Rotanfel'd, V. M.; Faytel'son, A. Sh.; Kalinin, N. A.; Volokh, A. G.; Namestnikov, Yu. G. \& Shleyfer, M. S., 1975. Relationship between structure of the basement and the sedimentary cover of the Baltic syneclise. Int. Geol. Rev. 17, 1392-1401.

Sederholm, J. J., 1967. Selected Works. Granites and Migmatites. Oliver \& Boyd, Edinburgh.

Simonen, A., 1980. The Precambrian in Finland. Geol. Surv. Finland, Bull. 304, 59 pp.

Stowe, C. W., 1980. Wrench tectonics in the Archean Rhodesian craton. Trans. Geol. Soc. S. Africa 83, 193-205.

Stålhös, G., 1984. Svecokarelian folding and interfering macrostructures in eastern central Sweden. In Kröner, A. \& Greiling, R. (Eds.) Precambrian Tectonics Illustrated. Schweizerbart., Stuttgart, pp. 369-379.

Tchalenko, J. S., 1970. Similarities between shear zones of different magnitudes. Geol. Soc. Am., Bull. 81, 1625 -1640 .

- \& Ambraseys, N. N., 1970. Structural analysis of the Dasht-e-Bayez (Iran) earthquake fractures. Geol. Soc. Am., Bull. 81, 41-60. 
Vaasjoki, M., 1977. Rapakivi granites and other postorogenic rocks in Finland: their age and lead isotopic composition of certain associated galena. Geol. Surv. Finland, Bull. 294, 64 pp.

Vivallo, W. \& Rickard, D., 1984. Early Proterozoic ensiallic spreading subsidence: evidence from the Garpenberg enclave, Central Sweden. Precambrian Res. 26, 203-222. Whickham, S. M. \& Oxburgh, E. R., 1985. Continental rifts as a setting for regional metamorphism. Nature 318, $330-333$.

Manuscript received September 23, 1986. 